大阪大学医兴部，第 1 解剖觉教穿（丰任：高木教授）と

第 2 內科学教室 (非: 福島教授).

I. Dept of Anat. (Director: Prof. 'TAKAGI) and II. Dept. of Intern.

Medicine (Director: Prof, FuKUsHIMA), Osaka Univ. Med. School.

\title{
朋臟部分切除後の膵臟の細胞学的研究.*
}

\section{A Cytological Study on External Secretion of Pancreas after Partial Hepatectomy.}

\author{
古永徹夫, 藤田 博, 鄭 義雄, 岡本 順。 \\ Tetsuo YOSHINAGA, Hiroshi FUJITA, Yoshio TEI \\ and Jun OKAMOTO.
}

[昭和 29 年 1 月 15 日原稿受付.]

著者等の一人吉永は部分的切除肝の再生並びそ機能について細胞学的飞 検索し，その結果については既飞詳細飞報告して居る。

そもとも肝臟と櫒臟との間には密接な関係があることは周知の事実であ り, 又肝臟部分切除と云う大きな侵襲飞際して, 膵臟飞も, その機能飞何 等かの恋化が起るととは当然予想される事である.

然しながら, 部分的切除肝の細胞学的変化飞平行して, 荟外分泌機能に 如何なる変化が起るかと云うととは，重要な問題を含んで居る．何故なら， 部分的切除肝の再生並び飞機能は, 食餌中の栄養素の含量及びその配合率 飞影響されること甚大であるが，之等栄養素の消化吸收に対する搭外分泌

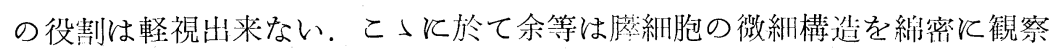
し，紐胞学:的観点より䑏外分泌機能をうかがった。

\section{I. 実驗方法と研究材料.}

実験動物はすべて体重 100-130g の雄大黒鼠を用いた。寒験開始飞先立 ち, 1 日 1 回, 一定時刻《30分間給食（カゼイン，澱粉，砂糖，肝油. 寒 天，McColl塩，オリザニン，水の定荲混合食及び青菜）し，他は水のみを

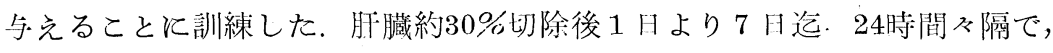
且つ24時間空腹時, 給食後 1 時間, 3 時間, 6 時間で屠殺し, 櫒臟一定部 位の一部をとり，直ち飞 Zenker 液, Kolster 液, Levi 液飞投入固定し, 型の如く脱水包埋, 切片作製を行い, Hematoxylin-Eosin 重染色, Heiden-

* 本論文の裂旨は昭和 28 年 4 月, 東京大学:に於て開催された第 39 回消化機病学会総 会に於て発表した。 
hain の iron-hematoxylin 染色等孝行った.

\section{II. 所 見.}

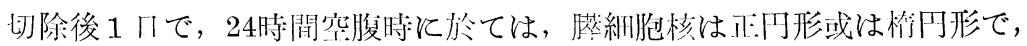
縕胞中尖部よりや」咸部と近く存し，紐胞尖端部より中去部とかけて，火

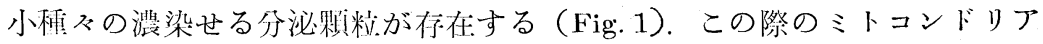
(以下ミトと略す) は稍飞細い糸状或は長桿状を呈し，細胞底より中尖部 そかけて散在する。分泌管腔は殆んど染色されず明澄である，以上の所見 を，正常膵細胞飞比較すると，切除 1 日後に於て，や」分泌顆粒の新生が 減少せるを知る。次と給食後 1 時間では，細胞核は依然として細胞中尖部 よりや」底部飞近く存し, 分泌顆粒は軽度に増量し, 中等大となり，ミト は減数し，連珠状，或は桿状を呈する。而して分泌管膛は依然明澄である。 食後 3 時間になると，細胞尖端部より中尖部とかけて，空胞が充満し，そ の中に大小種々の分泌顆粒の散在するを見る（Fig. 2，3）．更と時間を経 過すると，核は細胞の中尖部飞位し。核染色質は浱染し，空胞並びそ分泌 顆粒は減少して，細胞尖端部に僅少飞存在する。またミトは長，短桿状で， 細胞底部より中尘部にかけて散在する。即ちこの際，空胞肉容の放出が行 われたものと考光られる。

切除後 2 日で，2時間空腹時飞於ては，核は細胞の略尺中尖飞位し，小 さく，且つ核染色質は浱染し，核小体は大きい，分泌顆粒は中等大で，絒 胞尖端より中尖にかけて存在しミトは桿状をなすが，その数は少なく，且 つ細胞底部に江く散在する。分泌管坨は明澄である。而して，食後 1 時間 飞於てはミ卜はや」增数し, 分泌空胞も出現するが（Fig. 4), 食後の時間 が更飞経過するも，分泌顆粘の新生，放出の著明な像が見られない，切除 後 3 月、於ても, 腧外分泌機能の旺盛なる形態学的所見飞接しない. 然る 飞切除後 5 月になると, 分泌顆精は24時間空腹時飞於ても, 卙だ僅少であ るが，給食後ミトの增量が見られる様になり（Fig. 5), 分泌顆䊑の新生が ようやく恢復の才问间って来たことが知られる。而して切除後 7 日飞至 ると, ミトは更飞増数且つ増大し, 空腹時のみならず, 食後も糸状, 長桿 状，短桿状等の形態をとり，その一部は細胞尖端部に迄及ぶ，分泌管坨は， 空腹時飞於ては明澄で，空虚であるが，給食後は漲染し，分泌液の貯溜が 認められ，且つ核は小さく，核染色質は浱染し塊状をなす（Fig 6) 等， 分泌顆粒の新生、放出が泍次恢復して来たことを示すものである。然しな

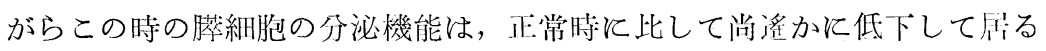
もの〉如くである. 


\section{III. 線括と考察.}

余等は肝歲部分切除後にあらわれる膵外分泌機能を, 縕佨学的観点飞立 って検索した。 そもそも荟外分泌は, 形態学的飞は, 分泌顆档の新生と放 出飞区別せられ，又との分泌顆粘はミトより生成される事は既に夙知の事 奏である。又分泌颗档は顆䊉のま〉放出される埸合と，空胞化して放出さ れる場合と，2通りあるとされて居るが，正常大黒鼠の膵細胞と於て，余 等の検索した所によると，給食前立びマ給食後には，分泌空胞形成を殆ん ど認めなかった故，顆粒分泌が主であると考觉る．然ると本実験に於て， 特飞切除後 1 日の給食後 3 時間では, 膵細胞尖端部飞多量の空胞の存在す るを認めた，文献とよると，町田（眧25-26）は，大黒鼠膵細胞に於て， 分泌空胞形成を見て居るが，氏はこれを以って，分泌物新生が旺盛なる時 に見られる所見なりと述べて居るが，余等の見る所では，新生に対して放 出が甚だ減弱したものと推測する。而してその理由は，分泌物新生の状沉 を物語るミト及び顆粒の所兒が，顆粒放出像に伴なわないからである．か くて切除後 2 日に至ると, 放出のみならず, 顆粓新生も低下し, 分泌空胞及 び顆粒が少ない，切除後 3 日と於てもこの状態は見られるが，5日目とな るとミトはや小活況を呈し，顆粒新生機能が先ず恢復の傾向を示す。7日 飞至ると, 新生機能が更に恢復すると共に, 給食後管脘に液の貯溜する等, 顆粒放出も漸次恢復しつ」あることが知られる. 次飞吉永の報告によれば 残存肝細胞の間接㤥分裂は，切除後 2 日に於て最子著明に見られ，又この 時期では，急激な 2 㤥細胞の減少が見られるが，荟蔵、於ても，この時期 では，分泌顆粒の新生並びそ放出が低下して盾る，木谷等は，肝部分切除 後, 血漿総蛋白量及びアルブミン量は，切除後 2 日目に急激に減少するが， その後漸次恢復すると述べて居る．膵外分泌と肝細胞微細構造の变化との 間に，直接関係を求めることは出来ないが，少くとも血獎蛋白量を介して， 密接な関係がうから゙われる。切除後12日頃より，漸次肝細胞微細構造も血 漿蛋白量も正常飞近づく様であるが，菜紐胞飞於ては，切除後７日頃より 恢復の徴が見られる。

\section{IV. 結 語.}

余等は朋部分切除後の膵外分泌の状況を，荟細胞微細構造を通じて，外 分泌を，分泌顆粒の新生と放出とに分けて観察した.

切除後 1 日より分泌低下があらわれ，切除後2-3月が最低となる。その

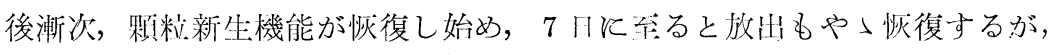
尚末だ正常よりは滛かと低下して腐る。 


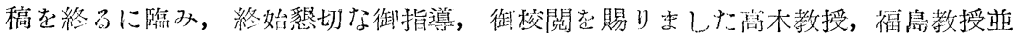
びに木谷助教授に心より感謝致します。

\section{Authors' Abstract.}

A cytological study was carried out on external secretion of pancreas after partial hepatectomy. From the next day the formation of secretary granules decreases, and the discharge of granules is inhibited more stronger than granule formation. At this time many secretary vacuoles appear 3 to 6 hours after feeding. As the days pass after partial removal of the liver, secretion and discharge of granules decreases more and more and arrives to its minimum on the 2 nd or $3 \mathrm{rd}$ day. On the 5 th day the formation of granules begins to take place again, and on the 7 th day discharge of granules occur again after feeding but is by much smaller than before the hepatectomy.

\section{文献.}

Arnold: The role of the chondriosomes in the cells of the Guinea-pigs pancreas. Arch. Zellforsch. 8 (1912). - Covall: A microscopic study of pancreatic secretion in the living animal. Anat. Rec. 40 (1928). - Cowdry: The general functional significance of mitochondria. Am. J. Anat. 19 (1916). P. 423. Bensley: Study on the pancreas of the Guinea-pig. Amer. J. Anat. 12 (1911).-Boenig: Die Histologie und Histogenese des Pankreas. - Bollman a. Mann: 'The physiology of the impaired liver. Ergb. d. Physiol. 38 (1936). S. 445. Brues, Drury a. Brues: A quantitative study of cell growth in regenerating liver. Arch. Path. 22 (1936). P. 658. - Fishtack: A morphologic study of regeneration of the Iiver after partial removal. Arch. Path. 7 (1929). P. 955. -

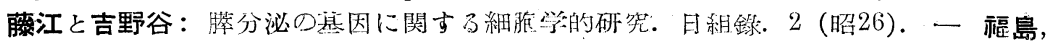
木谷, 吉永等：限剧性肝障得の代償. 日本內科誌. 42 (昭28). 真 425. 一 Higgins a. Anderson: Experimental pathology of the liver. Arch. Path. 12 (1931). P. 186. 一 木谷:

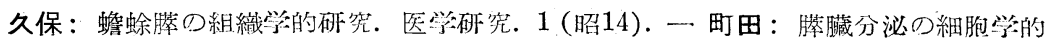
研究. I と II. 解剖誌. 25（昭25)，26（昭26). 一 Nasonow：Das Golgische Binnenetz und seine Beziehung zu der Sekretion. Arch. mikr. Anat. 97. (1923). - Novikoff a. Potter : Biochemical study on regenerating liver. J. biol. Chem. 173 (1948). P. 223. - Stowell: Nucleic acid and cytologic changes in regenerating rat liver. Arch. Path. 46 (1948). P. 164. - Takagi: Untersuchungen über die Unterkieferdrüse der Katze mit besonderer Berücksichtigung des Chondriosom. Z. mikro.-anat. Forsch. 2 (1925). 一吉永：肝臟の代償機能

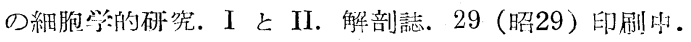

\section{附図說明。}

Fig. 1. 肝部分切除後 1 日，24㫢閏突腹時の膄細胞. 
Fig. 2. 肝部分切除後 1 日, 給食後 3 時閪の膵細胞.

Fig. 3. 同上.

Fig. 4. 肝部分切除後 2 日, 給食後 1 時間の膵細胞.

Fig. 5. 肝部分切除後 5 日, 給食後 1 時間の版細胞.

Fig. 6. 肝部分切除後 7 日, 給食後 1 時閻の膵細胞.

\section{Explanation of Plate.}

Fig. 1. Pancreas cells, 1 day after partial hepatectomy. Stomach emptied for 24 hours.

Fig. 2. Pancreas cells, 1 day after partial hepatectomy. 3 hours after feeding.

Fig. 3. 'The same as the above.

Fig. 4. Pancreas cells, 2 days after partial hepatectomy. 1 hour after feeding.

Fig. 5. Pancreas cells, 5 days after partial hepatectomy. 1 hour after feeding.

Fig. 6. Pancreas cells, 7 days after a partial hepatectomy. 1 hour after feeding. 


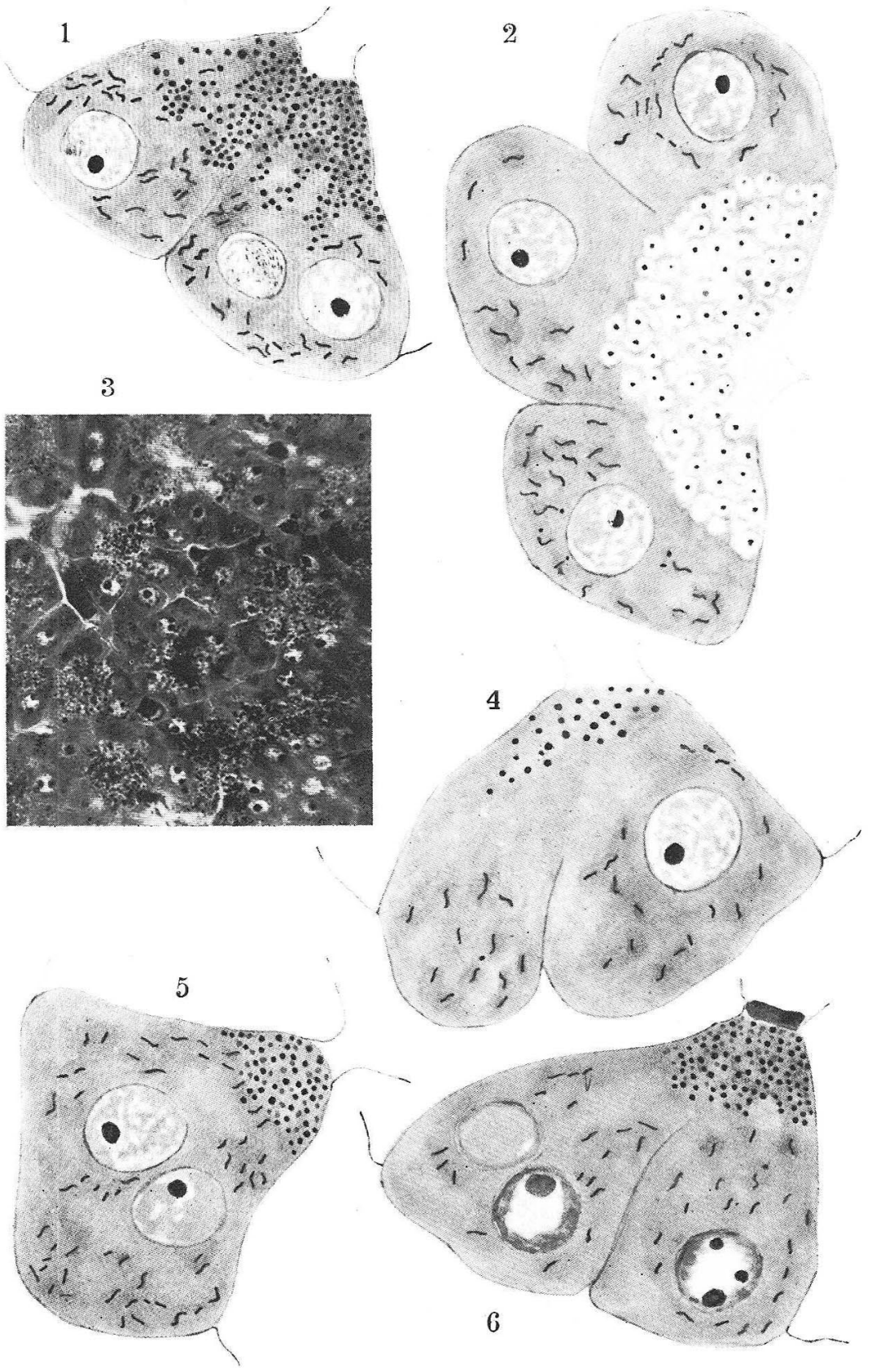

